\title{
Perilaku Pengguna Hijab dalam Mengatasi Masalah Rambut
}

Dwi Lukita Sari, Yenni Desilia Indahsari, Lukluk Afifatul Umroh, Hadi Nur Romadlon, Lisa Tri Agustin, Dias Putri Wardanasari, Septiani, Rama Syailendra Hadi, Ni Made Krisantina Shandra, Vindia Khendy Aksandra, Andi Hermansyah*

Program Studi Pendidikan Apoteker, Fakultas Farmasi, Universitas Airlangga, Surabaya

*Corresponding author: andi-h@ff.unair.ac.id

\begin{abstract}
Background: One of the factors affecting the condition of hair is the use of veil for woman. Woman who wears veil may suffer hair problems when the hair is not treated appropriately. Objective: This study aims to explore the behaviour of woman wearing veil to overcome their hair problems. Methods: Accidental non-random sampling was applied with sample of students wearing veil in Campus B Universitas Airlangga Surabaya. Data was collected using questionnaires and analyzed using SPSS. One hundred respondents participated in this study. Results: Majority of respondents was in the age of eighteen (31\%) mentioned hair fall as the major hair issues. Interestingly, 55\% of respondents did not use hair treatment frequently such as vitamin and conditioner. Majority of respondents was not aware of any synthetic/chemical hair fall treatment and anti-dandruff product. This may happen due to lack of knowledge about hair products. Conclusion: This study confirmed that respondents had adequate knowledge about hair problems, yet they had not applied such knowledge in practice.
\end{abstract}

Keywords: behavior, veil, hair problems

\begin{abstract}
Abstrak
Pendahuluan: Salah satu faktor yang mempengaruhi kesehatan rambut adalah penggunaan jilbab. Penggunaan jilbab berpotensi memicu terjadinya masalah rambut jika rambut tidak dirawat dengan benar. Tujuan: Tujuan penelitian ini adalah untuk mengetahui perilaku pengguna jilbab dalam mengatasi permasalahan rambut. Metode: Penelitian ini menggunakan metode survei dengan teknik pengambilan sampel accidental dan target sampel mahasiswi berjilbab di kampus B Universitas Airlangga Surabaya. Instrumen pengambilan data menggunakan kuesioner dan dianalisis menggunakan program SPSS (Statistical Product for Social Sciences). Seratus orang responden berpartisipasi pada penelitian ini. Hasil: Responden dengan usia 18 tahun merupakan responden dengan jumlah terbesar yaitu sebanyak $31 \%$ dan mengalami permasalahan rambut paling banyak yaitu rambut rontok. Menariknya sebanyak 55\% responden masih jarang untuk menggunakan produk perawatan rambut secara teratur termasuk vitamin dan conditioner. Mayoritas responden tidak mengetahui kandungan produk rambut dan/atau produk antiketombe yang mereka gunakan. Bahkan secara umum, responden tidak mengetahui produk yang benar untuk mengatasi permasalahan rambut. Kesimpulan: Penelitian ini menunjukkan bahwa responden telah mengetahui cara mengatasi permasalahan rambut namun belum diterapkan dalam tindakan yang rutin dan benar.
\end{abstract}

Kata kunci: perilaku, jilbab, kesehatan rambut

\section{PENDAHULUAN}

Kesehatan rambut dapat terganggu oleh beberapa hal, seperti defisiensi nutrisi, paparan terhadap panas/sinar UV/bahan-bahan kimia, polusi udara, tindakan pada rambut (pengeritingan, pelurusan, penggunaan pengering rambut, pengikatan), dan kelainan kulit kepala, misalnya kulit kepala berketombe dan infeksi kulit kepala seperti Tinea capitis (Lixandru, 2017). Rambut yang tidak sehat dapat menyebabkan rasa tidak percaya diri dalam berpenampilan, bahkan dapat menyebabkan stress yang justru memperparah kondisi rambut. Jika kondisi stress maka rambut akan mudah rontok, lekas berubah warna, hingga mengalami kebotakan (Dadang, 1996).

Terdapat dua faktor yang mempengaruhi kesehatan rambut yaitu faktor internal (berasal dari dalam diri 
sendiri) dan faktor eksternal (berasal dari luar). Faktor sedangkan faktor eksternal meliputi bleaching saat proses pewarnaan rambut, pengeritingan rambut, highlight dan pewarnaan, blowdry dan catok, mengikat rambut terlalu kuat dan metode perawatan rambut yang berlebihan (Pinuji, 2009). Salah satu faktor eksternal yang dapat mempengaruhi kesehatan rambut adalah penggunaan tutup kepala bagi wanita, termasuk penggunaan jilbab.

Penggunaan jilbab apabila tidak diiringi dengan perawatan rambut yang tepat dan rutin berpotensi menyebabkan permasalahan rambut. Sebagai contoh, penggunaan jilbab dalam jangka waktu yang lama dapat meningkatkan resiko rambut menjadi lebih lembab (Siregar, 2010). Angka kejadian ketombe juga diketahui meningkat pada pemakai jilbab (Ni'mah, 2011). Warna jilbab, jumlah lapisan kain jilbab dan penggunaan bandana juga berpengaruh pada munculnya ketombe pada wanita berjilbab (Fadhila, 2016).

Dikarenakan populasi pengguna jilbab yang besar ditambah lagi dengan kompleksitas permasalahan rambut, maka penelitian tentang kesehatan rambut pada pengguna jilbab menjadi relevan dan penting di Indonesia. Namun, penelitian yang ada saat ini masih terbatas pada investigasi permasalahan kesehatan rambut dan belum meneliti perilaku pengguna jilbab dalam mengatasi permasalahan pada rambut. Perilaku yang dimaksud termasuk bagaimana pengetahuan, sikap, dan tindakan pengguna jilbab dalam mengatasi masalah rambut. Oleh karena itu, penelitian ini bertujuan untuk mengidentifikasi "Perilaku Pengguna Jilbab dalam Mengatasi Masalah Rambut”.

\section{METODE}

Penelitian ini merupakan penelitian observasionalcrossectional dengan metode pengambilan sampel internal meliputi metabolisme, stress, dan hormonal accidental. Kriteria inklusi sampel adalah mahasiswi aktif di Universitas Airlangga kampus B yang memakai jilbab. Jumlah sampel sudah ditentukan yakni sebanyak 100 responden. Teknik pengambilan sampel dipilih responden yang kebetulan ditemui dan sesuai kriteria inklusi yang sudah dibuat. Pengambilan data dilakukan pada September 2018 di Universitas Airlangga Kampus B.

Instrumen yang digunakan untuk pengambilan data adalah kuesioner. Pertanyaan maupun pernyataan dalam kuesioner disusun berdasarkan kajian pustaka dan fenomena terkait penelitian, diskusi tim peneliti dan konsultasi dengan ahli. Terdapat empat variabel yang diteliti dalam kuesioner yaitu, (1) profil permasalahan rambut, (2) tingkat pengetahuan terhadap masalah rambut, (3) sikap terhadap masalah rambut, dan (4) tindakan responden terhadap masalah rambut. Kuesioner terdiri dari 37 pertanyaan dengan 7 pertanyaan menjawab variabel 1 , dan masing-masing 10 pertanyaan terkait variabel 2,3 , dan 4 . Pilot study dilakukan pada 20 responden untuk uji validasi. Perbaikan kuesioner dilakukan setelah mendapatkan hasil pilot study meliputi penambahan deskripsi penelitian, perbaikan pertanyaan dan pernyataan, serta tampilan kuesioner. Data yang diperoleh dianalisis secara deskriptif menggunakan program SPSS (Statistical Product for Social Science).

\section{HASIL DAN PEMBAHASAN}

Seratus orang responden berpartisipasi pada penelitian dengan sebaran usia sebagaimana terlihat pada Gambar 1. Usia 18 tahun merupakan responden dengan jumlah terbesar yaitu sebanyak $31 \%$.

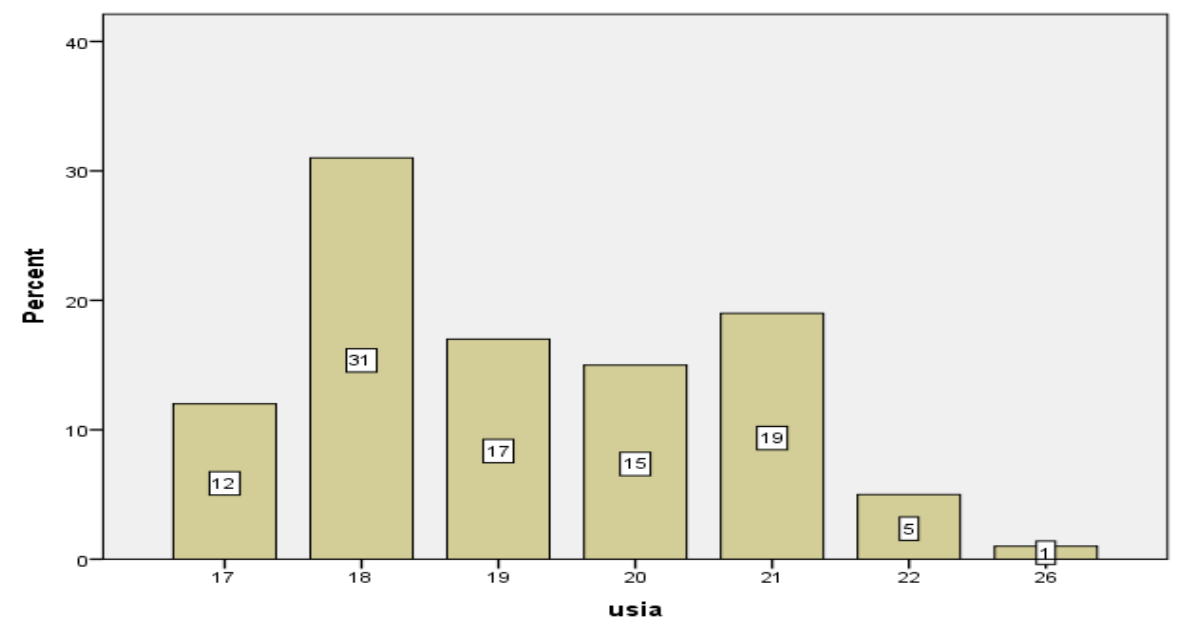

Gambar 1. Sebaran usia responden 
Tabel 1. Data crosstab usia dengan permasalahan rambut

\begin{tabular}{|c|c|c|c|c|c|c|c|c|c|c|c|c|c|c|c|}
\hline & \multicolumn{13}{|c|}{ Apakah anda memiliki permasalahan pada rambut? } & \multirow{2}{*}{ Total } \\
\hline & & Tidak & $\mathrm{R}$ & $\mathrm{Kt}$ & B & $\mathrm{Kr}$ & RKt & RB & $\mathrm{RKr}$ & $\mathrm{KrKt}$ & RKtB & $\overline{\mathrm{RKtKr}}$ & $\mathrm{KrBKr}$ & $\mathrm{RKrBKr}$ & \\
\hline \multirow{7}{*}{ Usia } & 17 & 0 & 6 & 2 & 0 & 0 & 1 & 0 & 3 & 0 & 0 & 0 & 0 & 0 & 12 \\
\hline & 18 & 0 & 13 & 5 & 0 & 0 & 8 & 0 & 2 & 1 & 2 & 0 & 0 & 0 & 31 \\
\hline & 19 & 0 & 13 & 0 & 1 & 0 & 3 & 0 & 0 & 0 & 0 & 0 & 0 & 0 & 17 \\
\hline & 20 & 1 & 4 & 0 & 0 & 2 & 2 & 1 & 2 & 0 & 0 & 2 & 1 & 0 & 15 \\
\hline & 21 & 1 & 12 & 0 & 1 & 0 & 2 & 0 & 0 & 0 & 2 & 0 & 0 & 1 & 19 \\
\hline & 22 & 1 & 1 & 0 & 0 & 0 & 1 & 1 & 0 & 0 & 0 & 1 & 0 & 0 & 5 \\
\hline & 26 & 0 & 0 & 0 & 0 & 0 & 1 & 0 & 0 & 0 & 0 & 0 & 0 & 0 & 1 \\
\hline \multicolumn{2}{|c|}{ Total } & 3 & 49 & 7 & 2 & 2 & 18 & 2 & 7 & 1 & 4 & 3 & 1 & 1 & 100 \\
\hline
\end{tabular}

Keterangan: R: Rontok, Kt: Ketombe, B: Bercabang, Kr: Kering, RKt: Rontok Ketombe, RB: Rontok Bercabang, RKr: Rontok Kering, KrKt: Kering Ketombe, RKtB: Rontok Kering Bercabang, RKtKr: Rontok Ketombe Kering, KtBKr: Ketombe Bercabang Kering, RKtBKr: Rontok Ketombe Bercabang Kering

Berdasarkan Tabel 1, responden dengan usia sekitar 18 tahun memiliki potensi lebih besar mengalami permasalahan rambut. Permasalahan rambut yang sering dialami responden yaitu rambut rontok sebanyak $49 \%$ responden. Pada dasarnya permasalahan rambut tidak dapat dikaitkan dengan faktor usia semata. Namun demikian, pada usia produktif, maka tingkat aktivitas akan mempengaruhi kesehatan rambut. Semakin tinggi aktivitas maka potensi permasalahan rambut semakin besar. Selain itu pada usia produktif, dalam konteks ini 18 tahun sebagaimana usia mayoritas responden, perubahan hormonal turut mempengaruhi kesehatan rambut. Ditambah lagi dengan kemungkinan stress dan pola diet yang tidak seimbang maka potensi permasalahan rambut akan menjadi semakin besar. Hal ini sesuai dengan studi yang menyatakan bahwa usia remaja banyak mengalami permasalahan terkait kesehatan rambut (CNN, 2018).

Gambar 2 menunjukkan bahwa mayoritas responden memiliki pengetahuan yang baik tentang permasalahan rambut. Sekitar $84 \%$ responden menjawab benar terkait penggunaan bahan kimia pada kosmetik rambut yang memicu permasalahan rambut. Selain itu 98\% responden menjawab benar bahwa paparan sinar matahari dapat mempengaruhi kesehatan rambut dan $86 \%$ responden menjawab benar terkait hormon yang mempengaruhi kesehatan rambut. Hal ini menunjukkan bahwa responden sudah mengetahui bahwa permasalahan rambut tidak hanya disebabkan oleh faktor eksternal seperti paparan lingkungan berupa faktor mekanis seperti trauma, tekanan dan tarikan, dan faktor fisik yang berasal dari air maupun radiasi sinar matahari dan sinar X (Horev, 2004) melainkan juga dapat disebabkan oleh faktor internal yaitu metabolisme, stress, dan hormonal.

Gambar 3 menunjukkan bahwa 60\% responden menyatakan setuju bahwa intensitas penggunaan jilbab dapat mempengaruhi kondisi rambut. Pernyataan lain menunjukkan sebanyak $60 \%$ responden setuju bahwa penggunaan jilbab lebih dari 12 jam dapat menyebabkan rambut lembap. Oleh karena itu, mayoritas responden (81\%) setuju untuk melakukan perawatan rambut, namun kurang dari separuh (49\%) masih ragu untuk melakukan perawatan rambut di salon. Sebagian besar (88\%) responden memilih perawatan mandiri dengan menggunakan conditioner dan vitamin rambut dalam menjaga kesehatan rambut. Hasil ini menunjukkan bahwa responden memiliki sikap untuk melakukan perawatan rambut ketika mengalami permasalahan rambut, meskipun yang banyak dipilih adalah perawatan secara mandiri. Namun, aspek sikap ini berbanding terbalik dengan aspek tindakan nyata responden dalam mengatasi permasalahan rambut.

Pada Gambar 4 menunjukkan bahwa 55\% responden masih jarang menggunakan vitamin rambut secara teratur dan 39\% responden jarang menggunakan conditioner. Menurut Angendari (2012), penggunaan kosmetika rambut dapat melindungi kulit kepala dan rambut dari pengaruh luar yang dapat merusak rambut seperti sinar matahari dan polusi udara. Namun pada studi ini sebagian besar responden tidak menggunakan kosmetika rambut dalam mengatasi permasalahan rambut. 


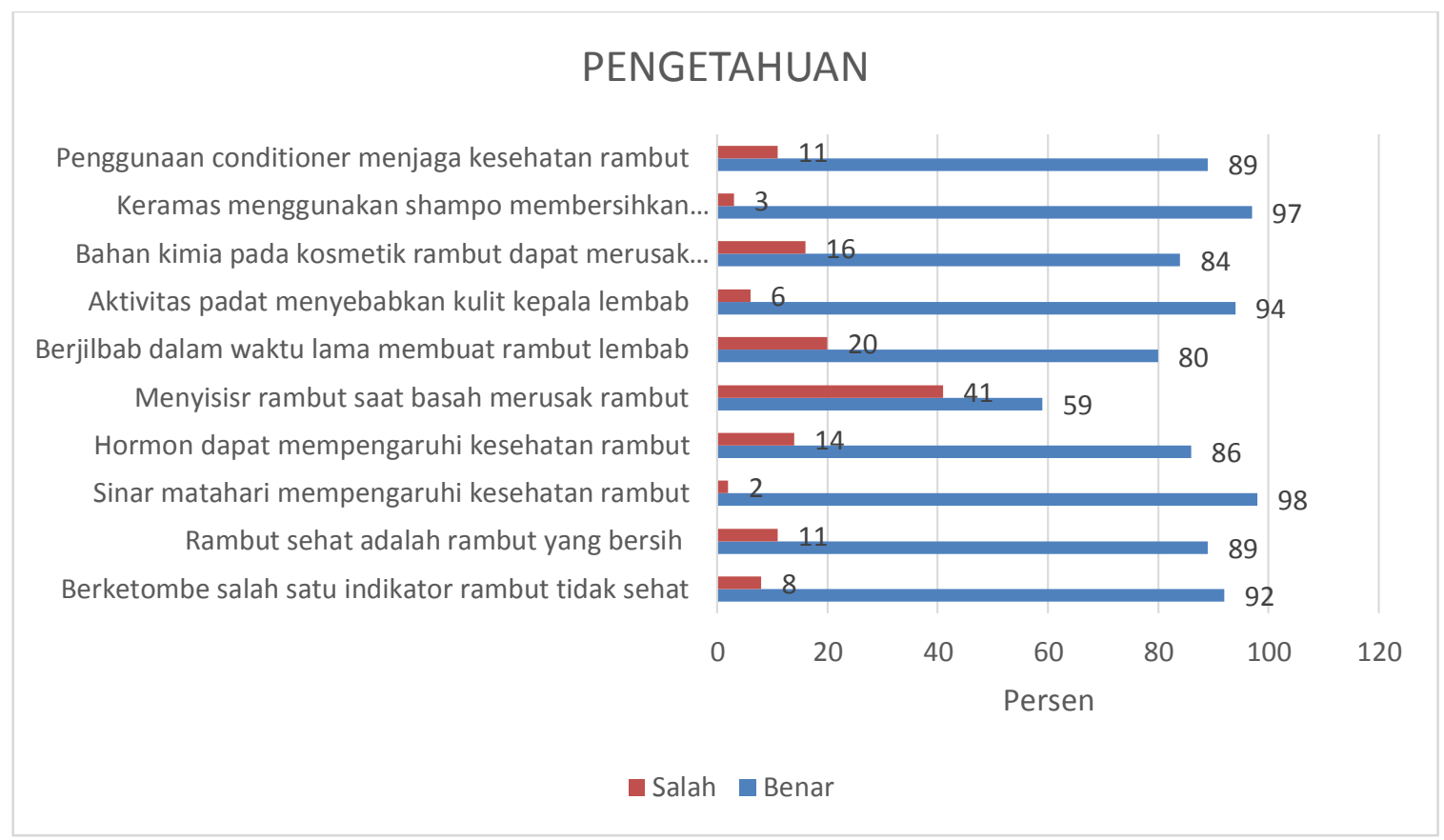

Gambar 2. Pengetahuan responden dalam mengatasi permasalahan rambut

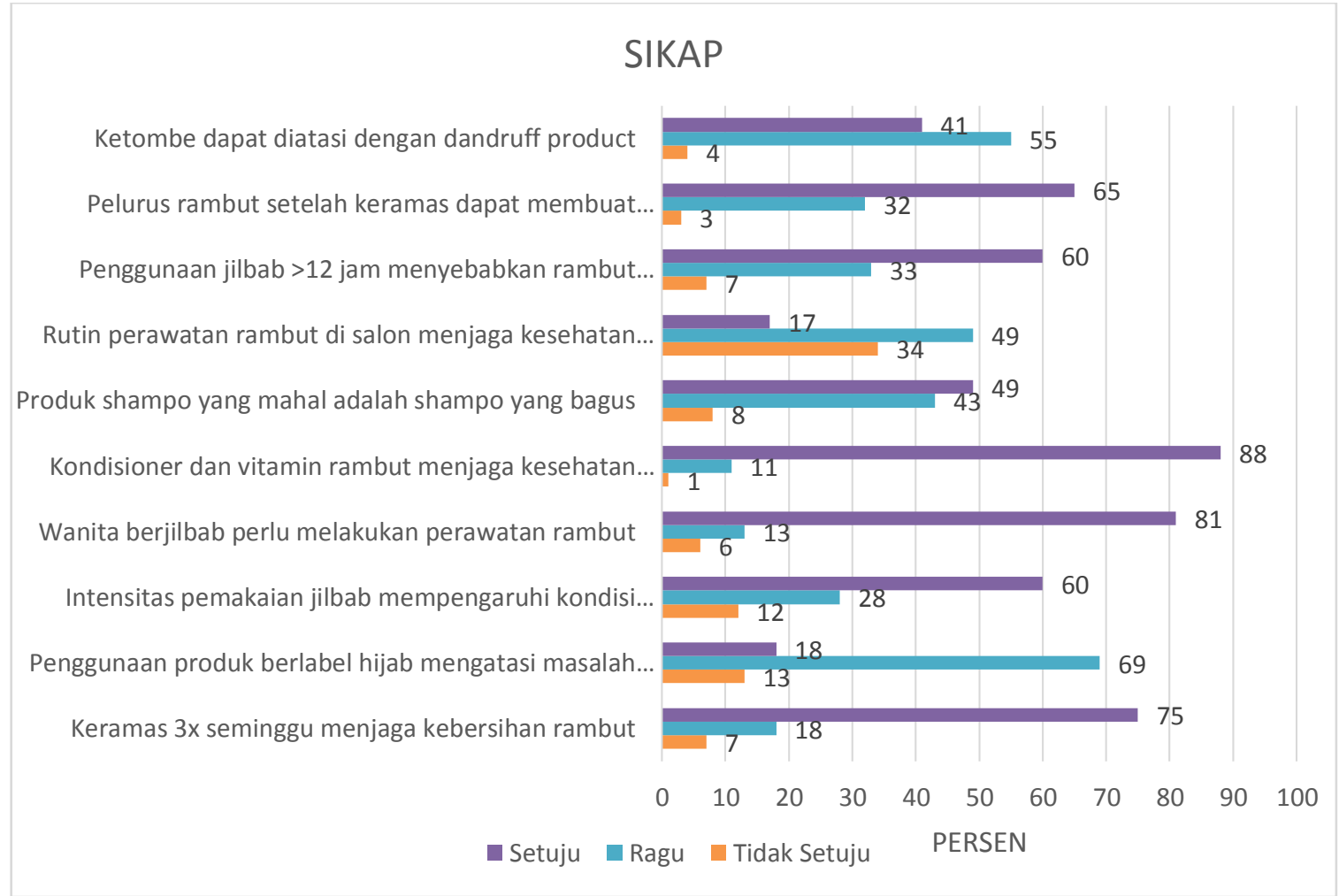

Gambar 3. Sikap responden dalam mengatasi permasalahan rambut 


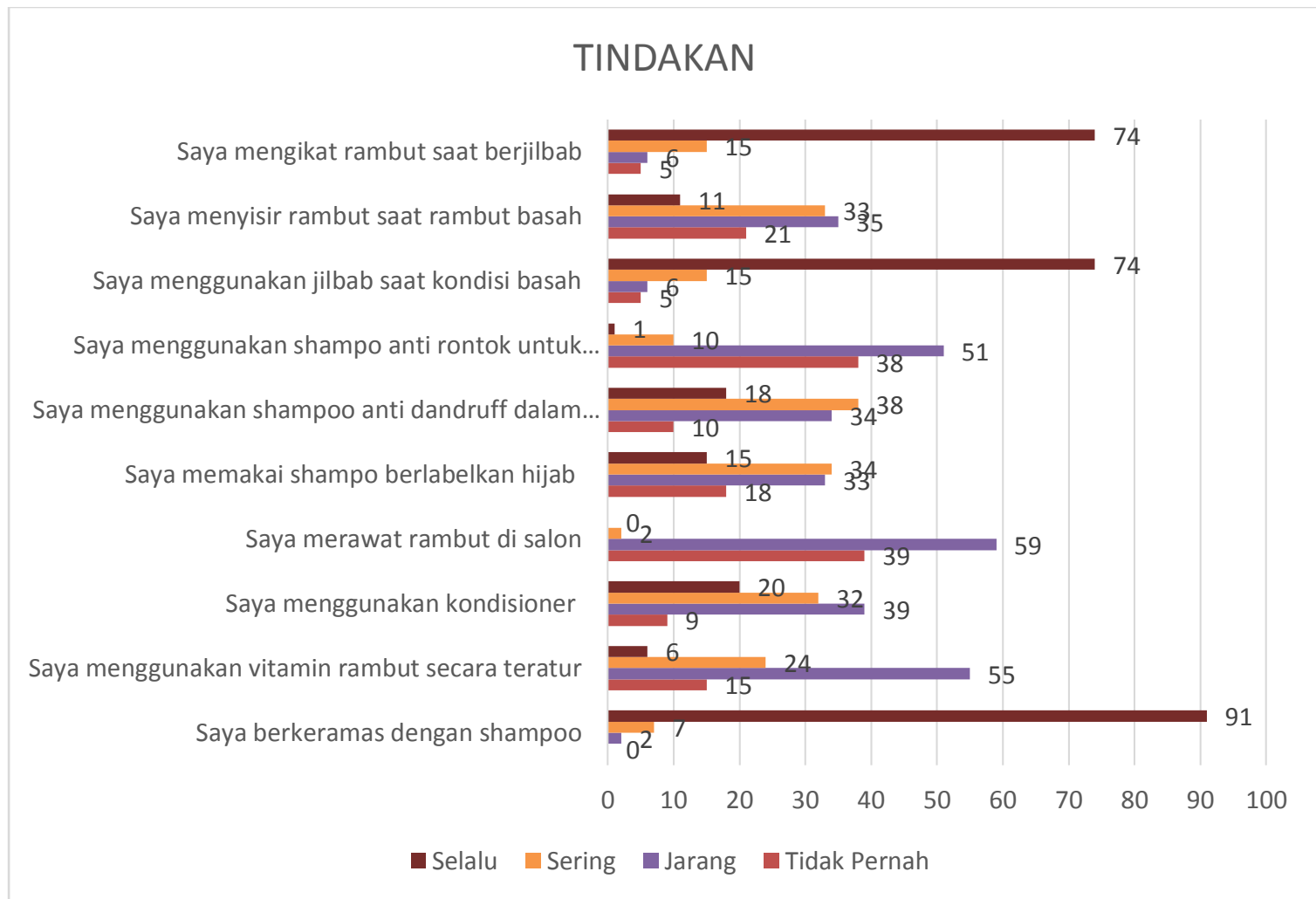

Gambar 4. Tindakan responden dalam mengatasi permasalahan rambut

Pada Tabel 2 sebanyak 91\% responden mengaku menggunakan shampoo antirontok namun mereka menyatakan bahwa tidak pernah menggunakan obat untuk mengatasi kerontokan rambut. Hal ini bertolak belakang dengan fakta bahwa dalam produk shampoo anti-rontok mengandung bahan kimia obat seperti minoksidil dan ketokonazole. Hal ini menunjukkan kemungkinan bahwa responden belum mengetahui kandungan dari shampoo antirontok.

Bahan kimia obat seperti minoksidil dapat mencegah rambut rontok dengan mekanisme kerja menstimulasi sintesis DNA folikular dan bekerja pada kanal kalium di rambut (Messenger \& Rundegren, 2004). Minoksidil juga dapat menyebabkan pemanjangan fase anagen dan peningkatan ukuran folikel rambut. Fase anagen berperan dalam fase aktif dari pertumbuhan rambut yang berlangsung dari beberapa bulan sampai beberapa tahun. Selain itu fase ini sebagai dasar dari folikel rambut dibentuk serta ditentukannya tebal, bentuk dan tekstur dari rambut (Messenger \& Rundegren, 2004). Terapi menggunakan minoksidil topikal dengan cara dioleskan 2 kali sehari dan pertumbuhan kembali rambut biasanya terlihat setelah penggunaan selama 12 minggu (Shapiro, 2002).

Tabel 2. Data crosstab cara mengatasi permasalahan rambut (rambut rontok)

\begin{tabular}{cccccc}
\hline & \multicolumn{2}{c}{ Saya menggunakan shampoo anti-rontok untuk rambut rontok } & Total \\
\hline $\begin{array}{c}\text { Apakah anda } \\
\text { menggunakan obat-obatan } \\
\text { untuk mengatasi masalah } \\
\text { rambut? }\end{array}$ & Tidak pernah & Jarang & Sering & Selalu & \\
\hline $\begin{array}{c}\text { Tidak Pernah } \\
\text { Ketokonazole }\end{array}$ & 10 & 29 & 35 & 17 & 91 \\
Selenium Sulfide & - & - & 2 & 1 & 3 \\
Obat Herbal & - & 1 & - & - & 1 \\
\hline TOTAL & - & 4 & 1 & - & 5 \\
\hline
\end{tabular}

Keterangan: $\mathrm{TP}=$ Tidak pernah, $\mathrm{J}=$ Jarang, $\mathrm{S}=$ Sering, $\mathrm{SL}=$ Selalu 
Berdasarkan hasil Tabel 3 sebanyak 91\% responden memiliki masalah dengan kesehatan rambut tetapi mereka mengaku tidak menggunakan obatobatan dalam mengatasi permasalahan tersebut. Sebanyak $73 \%$ responden yang mengaku pernah menggunakan produk antiketombe (31\% jarang, 30\% sering dan $12 \%$ selalu) memilih untuk tidak menggunakan obat-obatan. Hal ini menunjukkan bahwa responden sebenarnya tidak mengetahui bahwa produk antiketombe sebenarnya mengandung bahan kimia obat seperti zinc pirithion, selenium sulfit, dan ketokonazol berfungsi sebagai antifungal yang mampu menghambat pertumbuhan jamur Malassezia (Kementerian Kesehatan Republik Indonesia, 2014).

Tabel 3. Data crosstab cara mengatasi permasalahan rambut (ketombe)

\begin{tabular}{cccccc}
\hline & \multicolumn{2}{c}{ Saya menggunakan shampoo anti-dandruff untuk rambut } \\
berketombe & TOTAL \\
\hline $\begin{array}{c}\text { Apakah anda } \\
\text { menggunakan obat-obatan } \\
\text { untuk mengatasi masalah } \\
\text { rambut? }\end{array}$ & Tidak pernah & Jarang & Sering & Selalu & \\
\hline Tidak Pernah & 18 & 31 & 30 & 12 & 91 \\
Ketokonazole & - & - & 2 & 1 & 3 \\
$\begin{array}{c}\text { Selenium Sulfide } \\
\text { Obat Herbal }\end{array}$ & - & 1 & - & - & 1 \\
\hline TOTAL & - & 1 & 2 & 2 & 5 \\
\hline
\end{tabular}

Keterangan: TP $=$ Tidak pernah, $\mathrm{J}=$ Jarang, $\mathrm{S}=$ Sering, $\mathrm{SL}=$ Selalu

\section{KESIMPULAN}

Berdasarkan penelitian yang dilakukan dapat disimpulkan bahwa responden telah mengetahui permasalahan rambut dan cara mengatasi permasalahan pada rambut, namun belum memiliki pengetahuan tentang produk perawatan yang biasa mereka gunakan. Tetapi, sebagian besar responden belum menerapkan pengetahuan dan sikap tersebut dalam tindakan nyata untuk merawat kesehatan rambut secara rutin dan benar.

\section{DAFTAR PUSTAKA}

Angendari, M. D. (2012). Rambut Indah dan Cantik dengan Kosmetika Tradisional. Jurnal Pendidikan Teknologi dan Kejuruan; 9; 25-36.

CNN. (2018). Generasi Millennial Rentan Alami Kerontokan Rambut by CNN. https://www.cnnindonesia.com/gayahidup/20180305134729-255-280575/generasimillennial-rentan-alami-kerontokan-rambut. Accessed: 29 November 2018.

Dadang, H. (1996). Al Qur'an Ilmu Kedokteran Jiwa dan Kesehatan Jiwa. Jakarta: PT Dana Bakti Prima Yasa.

Fadhila, N. (2016). Prevalensi dan Faktor Risiko Terjadinya Ketombe pada Wanita Berjilbab. Skripsi; Fakultas Kedokteran Universitas Diponegoro, Semarang.

Horev, L. (2004). Exogenous Factors in Hair Disorders. Exogenous Dermatology; 3; 237-45.
Lixandru, M. (2017). Damaged Hair: Causes, Symptoms, and Treatment by Nature Word. https://www.natureword.com/damagedhaircauses-symptoms-and-treatment/. Accessed 1 September 2017.

Ni'mah, S. Z. (2011). Hubungan Penggunaan Jilbab dengan Kejadian Ketombe pada Mahasiswi Fakultas Kedokteran UNS. Skripsi; Fakultas Kedokteran Universitas Negeri Sebelas Maret, Solo.

Kementerian Kesehatan Republik Indonesia. (2014). Peraturan Menteri Kesehatan Republik Indonesia No. 5 Tahun 2014 tentang Panduan Praktek Klinis bagi Dokter di Fasilitas Pelayanan Kesehatan Primer. Jakarta: Menteri Kesehatan Republik Indonesia.

Pinuji, S. (2009). Dari Alam untuk Kecantikan Sempurna. Yogyakarta: Oryza.

Messenger, A. G. \& Rundegren, J. (2004). Minoxidil: Mechanism of Action on Hair Growth. British Journal of Dermatology; 150; 186-194.

Shapiro, J. (2002). Hair Loss: Principles of Diagnosis and Management of Alopecia. UK: Martin Dunitz.

Siregar, H. (2010). Makin Sehat dengan Berjilbab. Yogyakarta: Pro-U Media. 